\title{
Effects of Gamification on Behavioral Change in Education: A Meta-Analysis
}

\author{
Jihoon Kim ${ }^{1}$ and Darla M. Castelli ${ }^{2, *(1)}$ \\ 1 Physical Education Teacher Education, Department of Curriculum and Instruction, The University of Texas at \\ Austin, Austin, TX 78712, USA; jihoonkim@utexas.edu \\ 2 Health Behavior \& Health Education, Department of Kinesiology and Health Education, The University of \\ Texas at Austin, Austin, TX 78712, USA \\ * Correspondence: dcastelli@utexas.edu
}

Citation: Kim, J.; Castelli, D.M. Effects of Gamification on Behavioral Change in Education: A Meta-Analysis Int. J. Environ. Res. Public Health 2021, 18, 3550. https://doi.org/10.3390/ ijerph18073550

Academic Editor: William Evans

Received: 9 December 2020

Accepted: 18 March 2021

Published: 29 March 2021

Publisher's Note: MDPI stays neutral with regard to jurisdictional claims in published maps and institutional affiliations.

Copyright: (c) 2021 by the authors. Licensee MDPI, Basel, Switzerland. This article is an open access article distributed under the terms and conditions of the Creative Commons Attribution (CC BY) license (https:// creativecommons.org/licenses/by/ $4.0 /)$.

\begin{abstract}
Background: Gamified reward systems, such as providing digital badges earned for specific accomplishments, are related to student engagement in educational settings. The purpose of this study was to conduct a meta-analytic review to quantify the effects of gamified interventions on student behavioral change. Methods: A meta-analysis was performed using the following databases: The Academic Search Complete, Communication \& Mass Media Complete, Education Source, ERIC, Library Information Science \& Technology Abstracts, and PsycINFO. Inclusion in the review required: (a) peer-reviewed conducted between 2010 and 2019, (b) experimental controlled design, (c) gamification elements, and (d) educational setting. Results: Using a random-effects model, a statistically significant (Cohen's d $(E S)=0.48,95 \% \mathrm{CI}=0.33,0.62$ ) gamification effect was evidenced by moderate and positive grand effects sizes (ES). Gamification effects were higher with adults in higher education $(E S=0.95)$ than $\mathrm{K}-12$ students $(\mathrm{ES}=0.92)$. Brief interventions delivered in days or less than 1 week were significantly more effective $(E S=1.57)$ than interventions lasting up to 20 weeks $(E S=0.30)$. Interventions incorporating gamification elements across years $(E S=-0.20)$ was adversely associated with behavioral change. Conclusions: Findings suggest that short-term over longer-term gamified interventions might be a promising way to initiate changes in learner's behaviors and improve learning outcome.
\end{abstract}

Keywords: gamification; education; behavior change; badges; leaderboard; motivation; metaanalysis

\section{Introduction}

Motivation is a mental process that brings about and maintains goal-oriented actions [1]. It is essential for learning and the acquisition of knowledge [2]. One factor influencing teaching and learning is the increased $24 / 7$ access and reliance on the Internet and mobile devices. Expanded access to the Internet has changed the way we learn [3]. It is not just the expanded access to information, but also interactive social media, streaming videos, enabled online gameplay, and public health information that influence learning [4]. Online learning environments can be enriching because of timely student feedback and the multiplicity of platforms for expression and simulation. Given the paucity of research about gamified learning instructional strategies, the impact of such benefits needs to be quantified [5]. Specifically, online gamified learning as a motivational strategy in education and how gamification is related to student motivation and performance warrants further investigation. Empirical research is essential to determine the possible online gamification effects of badges, leaderboards, wearable devices, and community challenges to increase student motivation.

One common gamification method is the use of achievement badges. Typically, there is no practical value in being awarded a badge; however, attaining a badge creates a sense of satisfaction because receipt of a badge acknowledges progress toward accomplishing 
the desired outcome. The pursuit of badges is an emotional investment that symbolizes the magnitude of a challenge [5]. Using badges as rewards for achieving goals have a long history. For example, organizations like the Boy Scouts of America and Girl Scouts of America award badges for demonstrating a specific proficiency of a skill (e.g., starting a fire). For adults, airlines award elite status for meeting threshold amounts of travel [6]. The strength and utility of an educational badging system are related to the learning engagement and assessment. The conscious awareness of emotional commitment can enrich the learning experience and help the students see the inherent value of refining or obtaining a new skill. It is believed that the strength and utility of an educational badging system are associated with the context and should be directly aligned with the learning engagement and assessment strategies [7].

Commercially, gamification has been successfully integrated into platforms, especially social ones, to create targeted relationships between the software application and the users to drive viral behaviors that increase popularity [8]. It has been proposed that gamification likely has its place in education to increase student engagement and motivation to achieve learning standards [9]. Its potential benefits may address well-known issues as, e.g., the lack of student motivation due to the limited capacity of interaction with teachers and students [10].

Self-Determination Theory (SDT) is a motivation process with three emotional states of intrinsic motivation, extrinsic motivation, and amotivation [11]. SDT is grounded in three essential human psychological needs: competence, autonomy, and relatedness [12]. Competence, knowing that one was successful, can be enhanced from feedback for success [13]. Autonomy is defined as the degree to which individuals perceive themselves as responsible for the initiation of the behavior. Relatedness is the need to perceive that one can associate with others and with the social world in general [14]. Because gamification includes online badges, ownership, and leaderboard [15], it can be a factor covers competence, autonomy, and relatedness to fulfill intrinsic motivation.

Recent research has tried to find connections between SDT and gamification using meta-analysis. These find shows the overall significant, small positive effects of gamification on cognitive, motivational, and behavioral learning outcomes in a general learning environment [16]. Additionally, another meta-analysis confirms this result that gamification does appear to have a positive and significant small to medium effect on student learning outcomes in educational settings [17].

These studies led researchers to theorize that gamification could also be used in education as a tool to increase students' engagement and to drive them toward desirable learning behaviors [18]. The potential benefits of gamified learning may address public issues such as the lack of student motivation due to the limited interaction with teachers and students [19].

For this review, gamification was operationalized as any gamelike element applied in a non-game context like a learning environment [20]. Gamification is thought of as both a game element and as the process of creating gameful experiences to increase motivation to sustain desired behaviors [21]. The following gamification elements were examined within the review: badges, leaderboard, points, achievements, levels, story/theme, clear goals, feedback, rewards, progress, and challenge, because these have been linked to increased motivation [9]. Acquiring gamification rewards motivates the learner to participate in the educational environment and activities continuously. The action of earning badges can thus drive the acquisition of knowledge and skill [10].

Accordingly, this study aimed to summarize existing research related to using online gamification platform in education. This research was designed to answer the following research questions: How does gamification influence learners' motivation (e.g., participation level) and performance (e.g., test score)? Do gamification effects differ across age, length of the program, and type of outcome measure? We believed that this systematic review of the literature would reveal gaps in our understanding of how gamification is being used as an approach to increase motivation. We anticipated that gamification elements 
would have different degrees of influence on motivation and that such differences would be based on the characteristics of the sample, the chronological age of the participants, and the context or circumstance under which the gamification elements were being applied. Identifying and addressing the gaps in the literature has implications for gamification in an educational setting.

\section{Materials and Methods}

The present systematic review was conducted using the Preferred Reporting Items for Systematic Reviews and Meta-Analyses (PRISMA) [22] to identify the gamification effects on student motivation and performance in education. The number of gamification articles in $2010(n=63)$ has exponentially increased $(2019, n=1290)$, thus reflecting its importance as a motivational strategy in interventions.

\subsection{Procedure}

The PRISMA checklist was organized into the procedural steps of identification, screening, eligibility, and included. The PRISMA flowchart displays an overview of the process.

\subsubsection{Search Procedure and Selection Criteria}

At the outset of the review, each term of interest, "gamification" and "education", was operationally defined and used as a search term. Related antecedents or words that may have similar meanings were identified and included in the search, such as "online badges", "leaderboards", and "motivational affordance" were included in the search filters because it had been identified as keywords in other gamification publications. We excluded "gamebased learning" and "serious game" using the game itself rather than gamification that uses the application of game-design elements such as online badges and online leaderboard.

The search syntax was "gamification" AND "education" AND "motivational affordance" AND "online badges" AND "leaderboard" NOT ("game-based learning" AND "serious game" AND "online game"). The term "gamification" first appeared in 2008 [23], but it was not used widely in the research area until 2010 [24]. The search engines of Academic Search Complete, Communication \& Mass Media Complete, Education Source, ERIC, Library Information Science \& Technology Abstracts, and PsycINFO were used to identify relevant studies published between 2010 and 2019. Reference sections of studies were also examined to identifying additional studies that met the inclusion criteria.

The search findings were screened to eliminate any articles that do not meet the minimum inclusion criteria. For example, non-empirical articles or unpublished dissertations were excluded from the analysis. The following were the inclusion criteria for the review: (a) peer-reviewed, articles published in English, (b) empirical research with a control group, (c) gamification elements rather than on game-based learning or full games, (d) gamification was an independent or exposure variable, and (e) education setting.

Figure 1 displays the steps of identification, screening, eligibility, and inclusion that were carried out. Initially, 253 potential studies on gamification effects on learner outcomes were identified and screened. Fifty-eight duplicate articles were removed, while 12 additional articles were identified from the reference list of the original articles. After screening by the title and authors of the articles, there were another 86 records removed from consideration because 53 abstracts revealed that the article was not relevant to the current study, 20 articles were about exergaming only and did not include the gamification elements of interest in this review, and 13 articles were studies that were not conducted in an educational context. In the screening step, 101 abstracts were read, resulting in the elimination of 20 articles because these were not relevant to this present study. In addition, of the 101 abstracts, 83 potential citations were excluded. Because the articles were not experimentally designed to compare between an experimental and a control group for conducting a meta-analysis. 

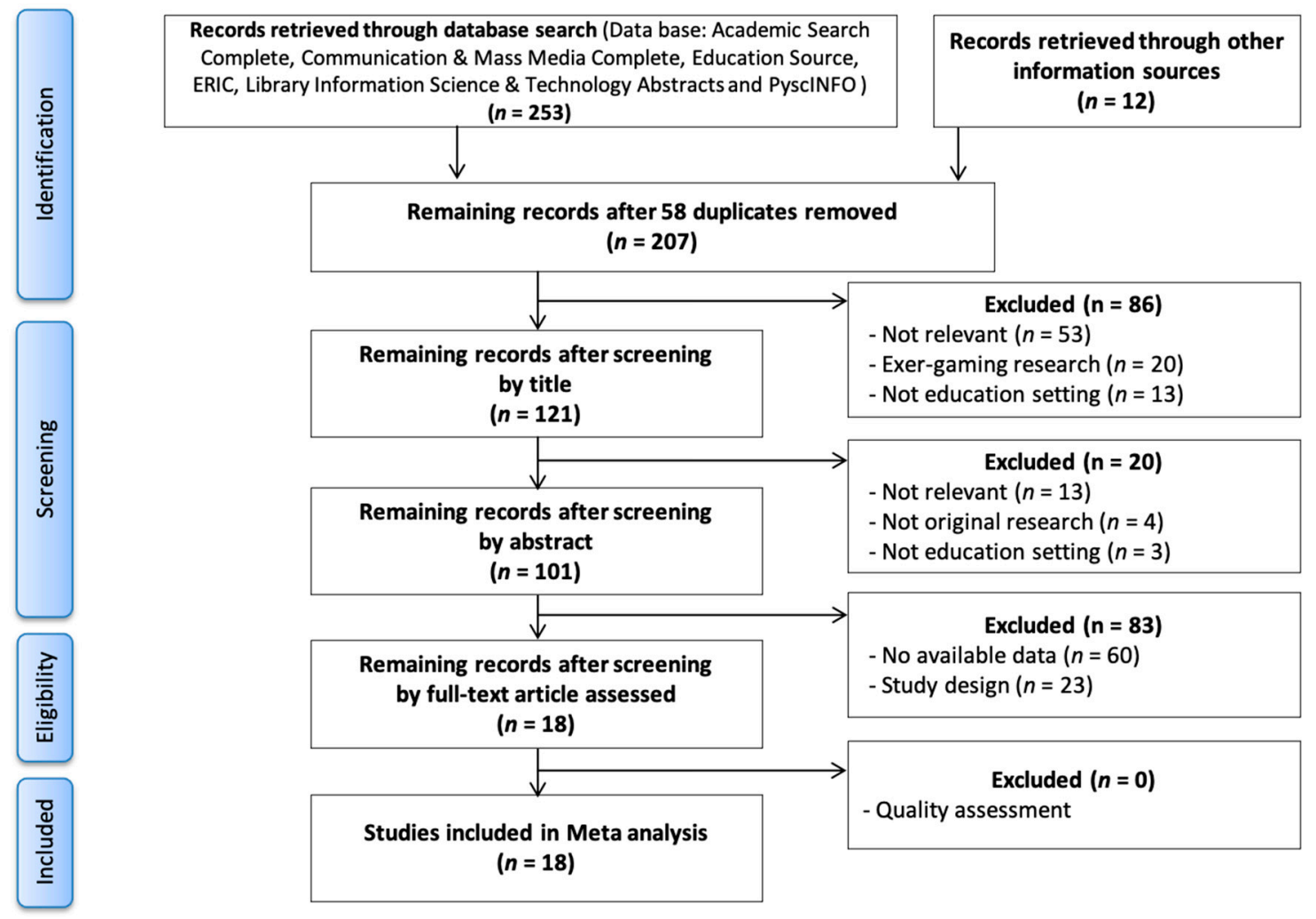

Figure 1. Preferred Reporting Items for Systematic Reviews and Meta-Analyses (PRISMA) flow chart.

\subsubsection{Assessment of Study Methodological Quality}

During the screening step, two reviewers inspected the full text of included studies and independently coded the research methodological to assess its rigor using the Downs and Black checklist [25]. The modified Downs and Black checklist permitted the reviewers to determine the quality of the research across different methodologies and approaches $[26,27]$. The modified checklist was utilized to analyze the study's validity and power more explicitly. With a sum score of 28 , the higher score indicated a higher level of methodological rigor. For example, if a power or sample size calculation was mentioned, it scored a 1. If the sample size and power calculation were explained and whether the number of participants was mentioned and appropriate for the addressed question, this also earned 1 point. All discrepancies between reviewers were resolved through research team debriefing and consensus. The percentage agreement for two raters was calculated for inter-rater reliability (reporting: $88.8 \%$, external validity: $90.6 \%$, internal validity: $91.4 \%$, and power: $94 \%$ ). Any study that scored relatively low on methodological quality was not considered for inclusion in the meta-analysis.

\subsubsection{Data Extraction and Coding}

Five categories of variables were extracted and coded from each of the included studies: (a) study characteristics (study year, author), (b) participant characteristics (age (k-12), college students, and adults), (c) intervention length (less than $1 \mathrm{~h}, 2-16$ weeks, and 1-2 years), (d) gamification type (online badges, leaderboard, levels, progress bar, points, and avatars), and (e) statistical data (control and treatment outcomes). Again, all codes were confirmed using two raters, research team debriefing, and consensus. The percentage agreement for two raters was calculated for inter-rater reliability (study characteristics: $95.5 \%$, participant characteristics: $93.9 \%$, intervention length: $84.8 \%$, gamification type: $81.8 \%$, and statistical data: $93.9 \%$ ). The primary outcome variables were defined as changes in learner's test scores and participation levels across three different age groups, intervention length, and measurement (Table 1). 
Table 1. Characteristics of gamification intervention studies included in the meta-analysis.

\begin{tabular}{|c|c|c|c|c|c|c|c|}
\hline Study (Year) & $\begin{array}{l}\text { Treatment } \\
\quad n\end{array}$ & $\begin{array}{c}\text { Control } \\
n\end{array}$ & $\begin{array}{l}\text { Age } \\
\text { Group }\end{array}$ & $\begin{array}{l}\text { Intervention } \\
\text { Length }\end{array}$ & $\begin{array}{l}\text { Measurement } \\
\text { Outcome }\end{array}$ & Gamification Affordance & $\begin{array}{l}\text { Education } \\
\text { Field }\end{array}$ \\
\hline $\begin{array}{l}\text { Allam et al. (2015) } \\
\text { [28] }\end{array}$ & 28 & 40 & Adult & Weeks & Test score & Badges, leaderboard, points & $\begin{array}{c}\text { Medical } \\
\text { education }\end{array}$ \\
\hline $\begin{array}{l}\text { Auvien et al. (2015) } \\
{[3]}\end{array}$ & $\begin{array}{l}215 \\
254\end{array}$ & $\begin{array}{l}215 \\
254\end{array}$ & $\begin{array}{l}\text { CS } \\
\text { CS }\end{array}$ & $\begin{array}{l}\text { Weeks } \\
\text { Weeks }\end{array}$ & $\begin{array}{l}\text { Test score } \\
\text { Test score }\end{array}$ & Badges, points & $\begin{array}{l}\text { Computer } \\
\text { science }\end{array}$ \\
\hline $\begin{array}{l}\text { De Marcos et al. (2017) } \\
\text { [29] }\end{array}$ & $\begin{array}{l}175 \\
177\end{array}$ & $\begin{array}{l}139 \\
139\end{array}$ & $\begin{array}{l}\text { CS } \\
\text { CS }\end{array}$ & $\begin{array}{l}\text { Weeks } \\
\text { Weeks }\end{array}$ & $\begin{array}{l}\text { Test score } \\
\text { PL }\end{array}$ & $\begin{array}{l}\text { Badges, leaderboard, points, challenge, } \\
\text { goals, levels, peer assessment }\end{array}$ & $\begin{array}{l}\text { Computer } \\
\text { science }\end{array}$ \\
\hline $\begin{array}{l}\text { De Marcos et al. (2014) } \\
{[30]}\end{array}$ & $\begin{array}{l}106 \\
112\end{array}$ & $\begin{array}{l}72 \\
72\end{array}$ & $\begin{array}{l}\text { CS } \\
\text { CS }\end{array}$ & $\begin{array}{l}\text { Years } \\
\text { Years }\end{array}$ & $\begin{array}{l}\text { Test score } \\
\text { PL }\end{array}$ & $\begin{array}{l}\text { Badges, leaderboard, points, } \\
\text { progress bar }\end{array}$ & $\begin{array}{l}\text { Computer } \\
\text { science }\end{array}$ \\
\hline $\begin{array}{l}\text { Denny et al. (2018) } \\
\text { [31] }\end{array}$ & $\begin{array}{l}702 \\
521\end{array}$ & $\begin{array}{l}702 \\
180\end{array}$ & $\begin{array}{l}\text { CS } \\
\text { CS }\end{array}$ & $\begin{array}{l}\text { Weeks } \\
\text { Weeks }\end{array}$ & $\begin{array}{l}\text { Test score } \\
\text { Test score }\end{array}$ & Badges, points & $\begin{array}{c}\text { Online } \\
\text { education }\end{array}$ \\
\hline $\begin{array}{l}\text { Hakulinen et al. (2015) } \\
\text { [32] }\end{array}$ & $\begin{array}{l}86 \\
86\end{array}$ & $\begin{array}{l}195 \\
195\end{array}$ & $\begin{array}{l}\text { CS } \\
\text { CS }\end{array}$ & $\begin{array}{l}\text { Weeks } \\
\text { Weeks }\end{array}$ & $\begin{array}{l}\text { PL } \\
\text { PL }\end{array}$ & Badges, leaderboard, points & $\begin{array}{l}\text { Computer } \\
\text { science }\end{array}$ \\
\hline $\begin{array}{l}\text { Hamari (2017) } \\
\text { [33] }\end{array}$ & $\begin{array}{l}1579 \\
1579 \\
1579 \\
1579\end{array}$ & $\begin{array}{l}1401 \\
1401 \\
1401 \\
1401\end{array}$ & $\begin{array}{l}\text { Adult } \\
\text { Adult } \\
\text { Adult } \\
\text { Adult }\end{array}$ & $\begin{array}{l}\text { Years } \\
\text { Years } \\
\text { Years } \\
\text { Years }\end{array}$ & $\begin{array}{l}\text { PL } \\
\text { PL } \\
\text { PL } \\
\text { PL }\end{array}$ & Badges & $\begin{array}{l}\text { Online trading } \\
\text { activity }\end{array}$ \\
\hline $\begin{array}{l}\text { Hanus \& Fox (2015) } \\
{[34]}\end{array}$ & 71 & 71 & CS & Weeks & PL & Badges, leaderboard & Communication \\
\hline $\begin{array}{l}\text { Harms et al. (2017) } \\
\text { [35] }\end{array}$ & $\begin{array}{l}21 \\
21\end{array}$ & $\begin{array}{l}19 \\
19\end{array}$ & $\begin{array}{l}\text { Adult } \\
\text { Adult }\end{array}$ & $\begin{array}{l}\text { Hours } \\
\text { Hours }\end{array}$ & $\begin{array}{c}\text { PL } \\
\text { Test score }\end{array}$ & Badges, avatar, progress bar & $\begin{array}{c}\text { Physical } \\
\text { activity }\end{array}$ \\
\hline $\begin{array}{l}\text { Huang and Hew (2015) } \\
{[36]}\end{array}$ & $\begin{array}{l}21 \\
21 \\
19\end{array}$ & $\begin{array}{l}19 \\
19 \\
16\end{array}$ & $\begin{array}{l}\text { CS } \\
\text { CS } \\
\text { CS }\end{array}$ & $\begin{array}{l}\text { Weeks } \\
\text { Weeks } \\
\text { Weeks }\end{array}$ & $\begin{array}{c}\text { PL } \\
\text { PL } \\
\text { Test score }\end{array}$ & $\begin{array}{c}\text { Badges, leaderboard, points, } \\
\text { progress bar }\end{array}$ & $\begin{array}{l}\text { General } \\
\text { Education }\end{array}$ \\
\hline Kim et al. (2016) & $\begin{array}{c}448 \\
448 \\
51\end{array}$ & $\begin{array}{c}299 \\
299 \\
47\end{array}$ & $\begin{array}{l}\text { CS } \\
\text { CS } \\
\text { CS }\end{array}$ & $\begin{array}{l}\text { Weeks } \\
\text { Weeks } \\
\text { Weeks }\end{array}$ & $\begin{array}{l}\text { PL } \\
\text { PL } \\
\text { PL }\end{array}$ & Badges, leaderboard & Engineering \\
\hline $\begin{array}{c}\text { Lam et al. (2018) } \\
{[38]}\end{array}$ & 22 & 30 & K-12 & Weeks & PL & Leaderboard, points, & ESL writing \\
\hline $\begin{array}{l}\text { Landers et al. (2015) } \\
\text { [39] }\end{array}$ & 33 & 49 & Adult & Hours & Test score & Leaderboard, points, & Brainstorming \\
\hline $\begin{array}{c}\text { Lombriser et al. (2016) } \\
{[40]}\end{array}$ & $\begin{array}{l}51 \\
51 \\
51\end{array}$ & $\begin{array}{l}21 \\
21 \\
21\end{array}$ & $\begin{array}{l}\text { Adult } \\
\text { Adult } \\
\text { Adult }\end{array}$ & $\begin{array}{l}\text { Hours } \\
\text { Hours } \\
\text { Hours }\end{array}$ & $\begin{array}{l}\text { PL } \\
\text { Test score } \\
\text { PL }\end{array}$ & $\begin{array}{l}\text { Badges, leaderboard, points, level, } \\
\text { challenges, avatar, progress bar, } \\
\text { storytelling, prize }\end{array}$ & Engineering \\
\hline $\begin{array}{c}\text { Ortiz-Rojas et al. (2019) } \\
\text { [41] }\end{array}$ & 55 & 34 & Adult & Hours & Test score & Leaderboard & $\begin{array}{l}\text { Computer } \\
\text { programing }\end{array}$ \\
\hline $\begin{array}{c}\text { Poondej et al. (2016) } \\
\text { [42] }\end{array}$ & 273 & 273 & CS & Weeks & PL & $\begin{array}{l}\text { Badges, leaderboard, point, } \\
\text { progress bar }\end{array}$ & $\begin{array}{l}\text { Information } \\
\text { literacy skills }\end{array}$ \\
\hline $\begin{array}{l}\text { Silpasuwanchai et al. } \\
\text { (2016) [43] }\end{array}$ & 19 & 6 & CS & Hours & PL & Badges, leaderboard, points & Memory \\
\hline $\begin{array}{c}\text { Turan et al. (2016) } \\
\text { [44] }\end{array}$ & 46 & 48 & $\mathrm{~K}-12$ & Weeks & Test score & Badges, leaderboard, points & $\begin{array}{l}\text { Technology } \\
\text { software }\end{array}$ \\
\hline
\end{tabular}

CS = college students; K-12 = kindergarten through 12th grade; ESL = English as a Second language; PL = participation level; Hours = less than $1 \mathrm{~h}$; Weeks $=2-16$ weeks; Years $=1-2$ years.

To determine the influence of moderator variables on gamification's overall effect size (ES) values for learner's behavioral change, we extracted three variables (age, intervention length, and measurement) from each included study. Age was classified as kindergarten through $12^{\text {th }}$ grade (K-12), college students, and adults. Two studies included $\mathrm{K}-12$, 10 studies included college students, and 6 studies included adults. Intervention length was classified as days, weeks, and years to discover whether variation in the length of the gamification intervention produced differential effects on the learner's behavioral change. Measurement outcome was categorized as a test score or participation level. When there was insufficient data information to compute an ES, we contacted the corresponding author of each related study via email to obtain means and standard deviation. 


\subsection{Data Analysis}

The researcher conducted a meta-analysis on the findings from the systematic review, using the codes from the PRISMA guidelines and the mean difference values from research articles. The mean ES values, along with $95 \%$ CIs, were estimated using a random-effects model for all outcomes [3,28-44] displayed in Table 1. To compute ES measures, mean group differences of final test score and participation level between gamification and control group were used. According to Cohen's [45] definition, ESs were classified as small $=0.2$, medium $=0.5$, and large $=0.8$.

The heterogeneity of weighted mean ES was examined through moderator analysis using Cochran's Q statistics (Q) [46]. When the Q statistic was significant $(p<0.05)$, it indicated heterogeneity of effects, so we performed additional analyses to examine the effect of each moderator. The amount of potential publication bias was also analyzed via visual inspection of a funnel plot and Egger's test of the regression intercept and used this as a final determination for inclusion. All statistical data analyses were conducted using Comprehensive Meta-Analysis version 2 software program that provides a complete set of analytical ways to conduct a meta-analysis [47].

\section{Results}

A total of 253 publications from 5 databases and 12 potentially relevant studies from the reference lists of the included articles were considered for further review. After a preliminary review, 58 studies were eliminated due to their inability to meet criteria and duplication. We retrieved information from the remaining 207 studies first by title and abstract, then by full-text, but upon screening these studies did not meet the inclusion criteria (i.e., 86 and 20 studies by step). Full texts of the remaining 83 studies were reviewed for a detailed assessment. A total of 18 studies provided sufficient data to compute an ES and were included in this analysis. The methodological quality of the included studies was fair (mean \pm standard deviation (SD) $17.11 \pm 1.37$, ranging from 15 to 20 , considering the maximum score of 28) according to the previous research [27]: excellent [26-28], good [20-25], fair [15-19], and poor $(<15)$. No studies had quality scores outside two standard deviations of the mean. Average scores for each measurement domain were: (a) reporting $(9.00$ of 11$)$, (b) external validity (0.94 of 3), (c) internal validity (7.17 of 13$)$, and (d) power: (0 of 1$)$.

\subsection{Overall ES}

The weighted mean ES values, 95\% confidence interval (CI), and a forest plot are provided in Figure 2. Overall, 32 ESs were calculated from the 18 studies. The results from ES calculations indicated that the treatment (gamification) effect was statistically significant $($ Cohen's d $(E S)=0.48,95 \% \mathrm{CI}=0.33,0.62)$, moderate, and positive mean ES, using a random-effects model. This finding indicated that gamification is a useful motivational tool to increase learner's behavioral outcomes. 


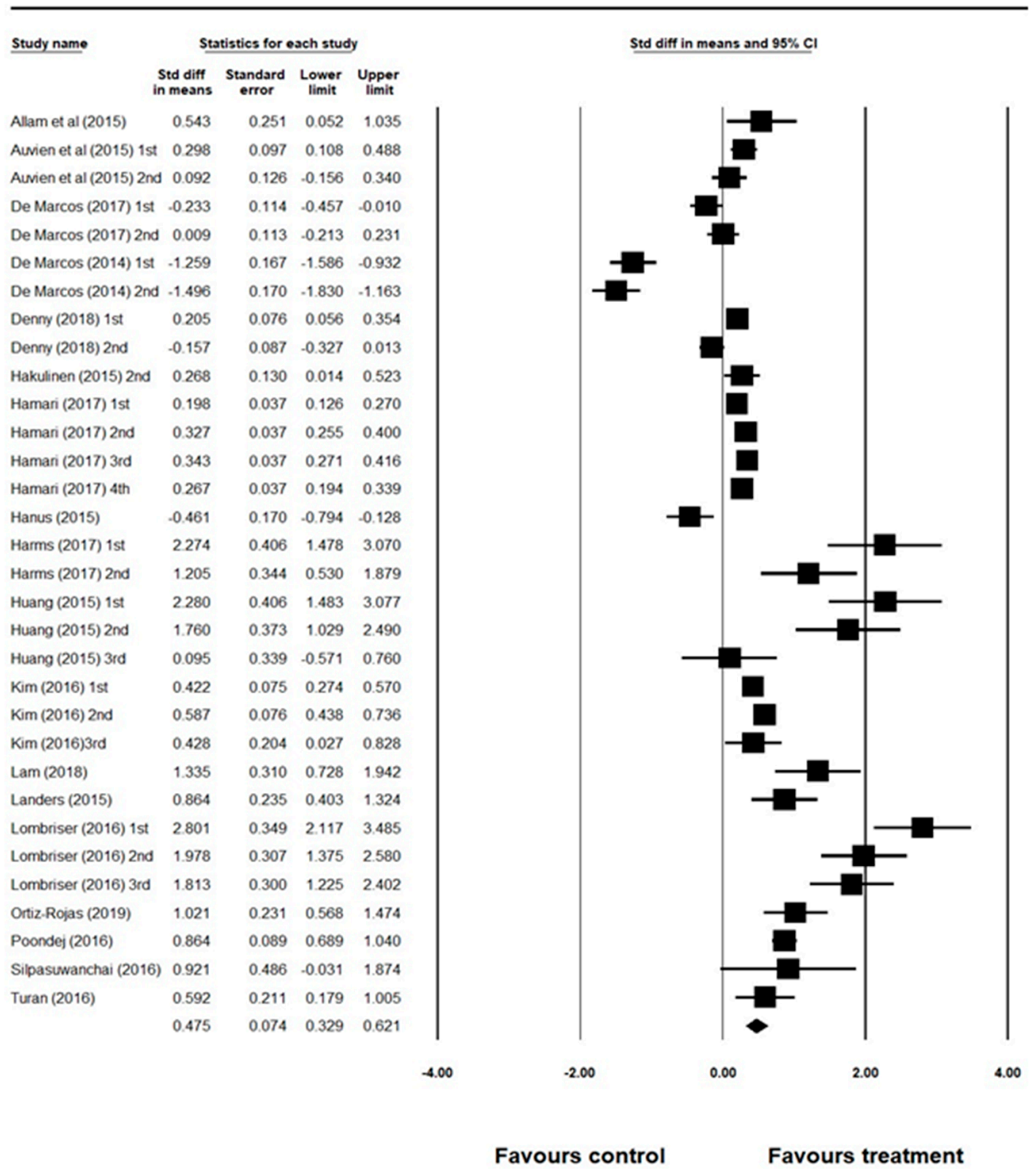

Figure 2. Standardized mean difference effect sizes, 95\% CI and a forest plot.

\subsection{Moderator Analysis}

Moderator analyses were performed to examine the effect of age (i.e., K-12, college students, and adults) and intervention length (i.e., days, weeks, and years) as independent variables and measurement (i.e., test score and participation level) as dependent variable on overall weighted mean ES. Table 1 indicates the results of moderator analysis, which provides ES, 95\% CI, and Cochran's Q statistic for each moderator variable (Table 2.) Cochran's $Q$ test is a nonparametric statistical test that assesses whether the treatments have the same effects among groups [48].

The results of moderator analysis indicate that the $Q$ statistic for the age (K-12, college students, and adults) and intervention length (less than $1 \mathrm{~h}, 2-16$ weeks, and 1-2 years) were statistically significant. The $\mathrm{Q}$ statistic for age, $\mathrm{Q}$ between $(\mathrm{Qb})=26.27, \mathrm{df}=2, p<0.01$, explained the heterogeneity of ESs. The adults intervention $(E S=0.95,95 \% \mathrm{CI}=0.70,1.12)$ appeared to be more effective than $\mathrm{K}-12(\mathrm{ES}=0.92,95 \% \mathrm{CI}=0.29,1.55)$ and college students intervention $(E S=0.15,95 \% \mathrm{CI}=-0.04,0.35)$. The $\mathrm{Q}$ statistic for the intervention length also indicated that less than 1 -h intervention $(E S=1.57,95 \% \mathrm{CI}=1.25,1.90)$ appeared to be 
more effective than $2-16$ weeks $(\mathrm{ES}=0.39,95 \% \mathrm{CI}=0.21,0.57)$ and $1-2$ years $(\mathrm{ES}=-0.20$, $95 \% \mathrm{CI}=0.40,0.77)$ intervention groups in behavioral change.

Table 2. Effect sizes by moderator variables in the meta-analysis.

\begin{tabular}{|c|c|c|c|c|c|c|}
\hline \multirow{2}{*}{\multicolumn{2}{|c|}{ Moderator Variables }} & \multirow{2}{*}{$n$} & \multirow{2}{*}{ ES } & \multicolumn{2}{|c|}{$95 \% \mathrm{CI}$} & \multirow{2}{*}{$\mathrm{Qb}$} \\
\hline & & & & Lower & Upper & \\
\hline \multirow{3}{*}{ Age } & $\mathrm{K}-12$ & 146 & 0.92 & 0.29 & 1.55 & \multirow{3}{*}{$26.27^{* *}$} \\
\hline & College students & 5780 & 0.15 & -0.04 & 0.35 & \\
\hline & Adults & 12,455 & 0.95 & 0.70 & 1.12 & \\
\hline \multirow{3}{*}{$\begin{array}{l}\text { Intervention } \\
\text { length }\end{array}$} & Days & 492 & 1.57 & 1.25 & 1.90 & \multirow{3}{*}{$67.20 * *$} \\
\hline & Weeks & 12,282 & 0.39 & 0.21 & 0.57 & \\
\hline & Years & 18,381 & -0.20 & -0.47 & 0.09 & \\
\hline \multirow{2}{*}{ Measurement } & Test score & 3059 & 0.30 & 0.03 & 0.18 & \multirow{2}{*}{3.38} \\
\hline & Participation level & 15,322 & 0.60 & 0.40 & 0.77 & \\
\hline
\end{tabular}

\subsection{Publication Bias}

Meta-analysis results may not describe the population of interest due to publication bias, which happens when studies with statistically significant results tend to be published than studies with statistically nonsignificant results. The funnel plot was created to assess the presence of publication bias (Figure 3). When publication bias has occurred, sections of the funnel may be missing, or the plot may become very asymmetrical [49]. The plot appears to be more positive effects than negative ones; however, Egger's test of regression intercept was $1.46(p=0.22)$, which indicates that the potential for publication bias was minimized across the studies.

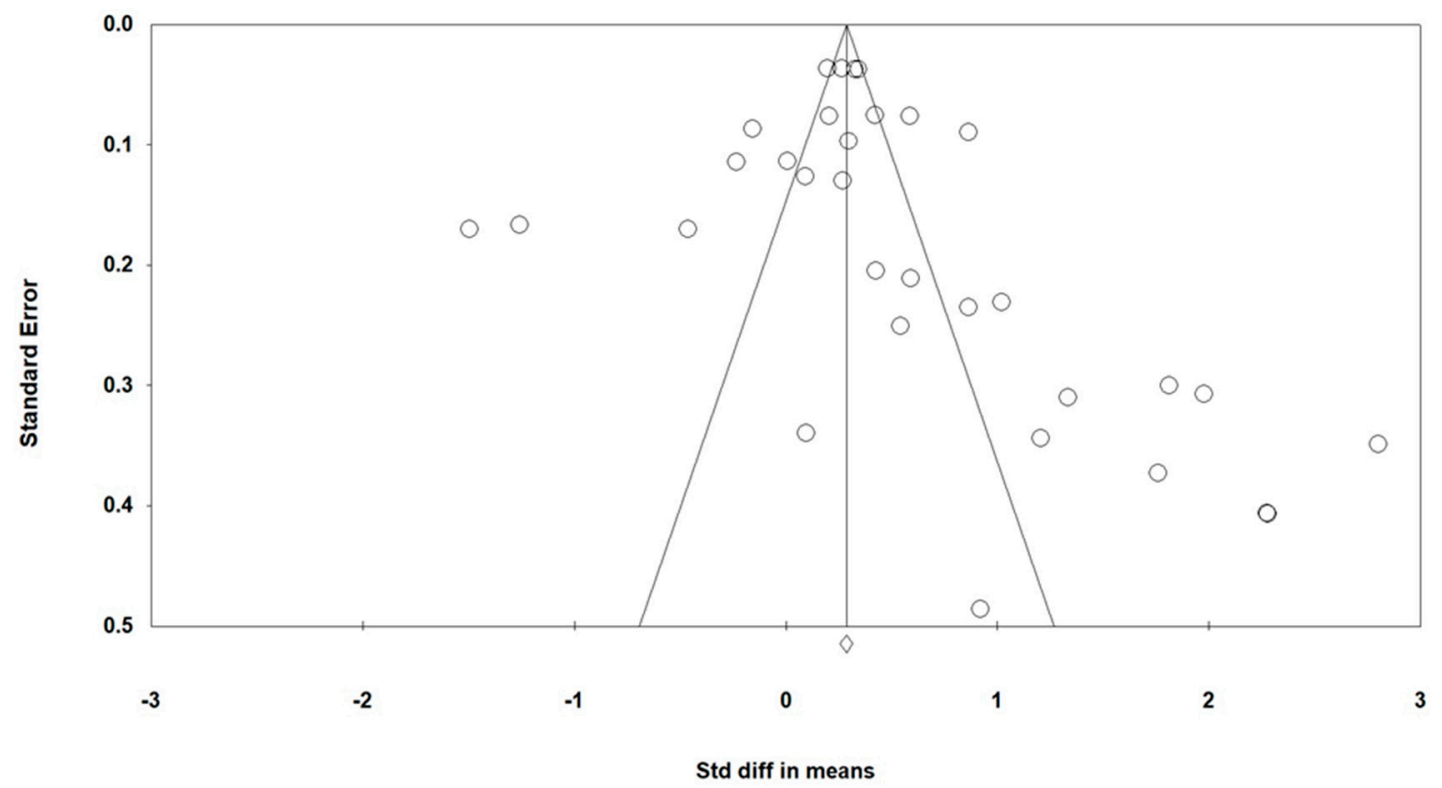

Figure 3. Funnel plot of all 32 effects from treatment and control samples.

\section{Discussion}

We examined the relationship between gamification, as specific elements and as a process, and a behavioral change in education settings using the meta-analysis technique. The results show that the gamification strategy has a moderate, positive effect on engagement behaviors and test scores. This study also examined if age, intervention length, and measurement type influence the effectiveness of the gamification intervention. The findings in this study are based on 32 data sets from 18 experimental design studies. We 
realize that this body of literature is growing exponentially and that even though this is an adequate volume of experimental data to conduct these analyses, we acknowledge that additional experimental research was conducted concurrently and could not be included in this review. Consequently, this is viewed as one of the leading researches $[16,17]$ to quantify and qualify gamification effects in educational settings using meta-analysis.

\subsection{Developmental Stage and Gamified Interventions}

In the present study, participants were categorized into three different age groups (K-12, college students, and adult non-student), where each group has a different ratio of the amount and estimated their ESs. There is a significant difference in ESs between the three age groups in this study. The gamified intervention effects were most significant for older adults compared to those of K-12 and college students. This result indicates that there might be a possibility that younger age people and older people were more interested in gamified factors in education than college students' age groups. Contextual and developmental factors may have influenced the effectiveness of interventions focused on these portions of the lifespan, but such an analysis was beyond the scope of this review.

Older adults demonstrated the highest engagement compared to college students and K-12 students. Wang and colleagues [50] found that older users are more easily influenced by social modeling than younger adults. Leaderboards are a mechanism of social comparison. One's place or absence on the leaderboard can have differential effects related to mastery and ego-oriented motivation. The more inferior effect of social influence on the younger generation, maybe because they have been exposed to a gamified strategy at a younger age [51]. This result was contrary to previous research that the influences of age in technology adoption and usage have designated that younger technology users value the technology's usefulness more than older [52]. As a transitional stage, it can be assumed that young adults possibly lost their interest in gamified features that they held when they are young. Older participants are attracted to the gamified elements because they emphasize ease of achieving goals by reflecting progress [53]. The novelty of the gamified elements is likely driving the effects [54]. Over time, college students age and developmental stage have shifted away from exclusively emerging adulthood to representing a diversity of developmental stages across the lifespan. Instructors in higher education need to be aware that gamification could be useful for more non-traditional and older adults. These finding warrants further investigation to understand the effects of a gamification strategy in education by age groups.

\subsection{Length of Gamified Interventions}

Given the data reviewed in this study, there is an optimal length of gamified interventions. People often prefer short-term rewards rather than long-term rewards in modern life [55], and this cognitive inclination is called hyperbolic discounting [56]. Gamified interventions lasting days were significantly more impactful than those lasting 1-2 years. This finding provides a practical implementation that learners possibly have more motivation for learning or participation in intensive, short-term scenarios than in extended education settings [57]. It is recommended that we investigate students' needs and motivations to carefully plan and examine the rewarding design, considering timing and duration to adequately address the motivational affordances that create compelling socially gamified learning experiences [58]. Further, the timing of new challenges (e.g., gamified as levels or events) and how long it takes someone to earn a new badge) need to be investigated in relation to the developmental stage, context, and intervention length, as more data are needed to support the reliability of this assertion.

\subsection{Behavioral Change and Learning Outcome}

This study indicated ESs for different outcome measurements to examine if gamification affects differently on outcome measurements such as participation level and test score. These results have shown that there is no significant difference in outcome measurement. 
However, participation level $(\mathrm{ES}=0.60,95 \% \mathrm{CI}=0.40,0.77)$ had higher effect size than those of test score $(E S=0.30,95 \% C I=0.03,0.18)$. This result suggests that gamification has more effect on a learner's participation level than a test score. Increased learning time, such as participation level, may develop learning skills and academic achievement [59]. Subsequently, it is expected that educators improve learners' participation levels (e.g., learning time) using gamification strategy, impacting learning outcomes [60].

\subsection{Study Delimitations and Limitations}

These meta-analysis findings are significant because gamification is an emerging and growing issue in education [58]. Although this direct mechanism has not yet been adequately investigated in educational settings, it has been confirmed that the gamification strategy increased the learner's behavioral change, including test score and participation level. Therefore, although limited in scope, experimental investigation supports the hypothesis that gamification motivates learners' positive reviewers' change. This study's main strength was the deliberation of gamification as a motivation strategy for learners' positive behavioral change and learning outcome in education. This study has also shown the moderating effect of age group, intervention length, and measurement type, which could help plan gamification-based education programs.

Another distinctive characteristic of this study was the methodological quality. The average Downs and Black Scale total score was fair (mean \pm standard deviation (SD) $17.11 \pm 1.37$, ranging from 15 to 20 , considering the maximum score of 28). Consideration of study quality is a unique feature of this gamification study. The meta-analysis has shown that gamification affects learners' positive behavioral change, but there are limitations explaining its impact on learners' behavior. Most of the studies used diverse gamification elements, including online badges and leaderboards only, and some combined with other sources such as progress bar or rewards points. Future research should aim to use objective measurable treatments, e.g., online badges and leaderboards only.

All studies in this meta-analysis were quasi-experimental instead of randomized control experimental design because there are limitations for conducting randomized sampling in an educational setting. Although the overall ES of our study demonstrated that the gamification strategy has moderate effects on the learner's behavioral change (ES $=0.48)$, the results should be interpreted with caution due to the lack of casual outcomes. Based on the funnel plot, studies indicating that the publication bias was minimized across the studies.

\subsection{Implications for Gamified Educational Learning}

The present study examined the overall ES of gamification on learners' behavioral change. The evidence suggests that gamification has a moderate and positive effect on learner's behavioral change in gamified intervention studies. The results indicated that gamification impacts are similar across all types of outcome measurements. However, the different age groups and intervention lengths have a diverse effect on the learner's behavioral change. The gamification effect on college students is relatively lower than those of school ages students and adults. However, a fundamental question driving every meta-analytic research is generalizability [61]. Therefore, it should be careful to conclude that college students are not highly motivated by the gamified teaching method. However, this result can imply that educators should be cautious in designing game mechanics at college-level programs.

Contrary to previous findings suggesting that gamified interventions of 20 weeks offering badges to children who participated in physical activity breaks in the classroom significantly increased children participation [7], the summary of research, in comparison to college students and older adults, did not produce the same degree of behavior change. Short-term gamification intervention with K-12 students in their participation level has shown the comparatively most significant effect of learners' behavioral change, and so we would advocate for its continuation, but recommend that intervention length, gami- 
fication elements and its timing, and developmental stage be thoughtfully mapped onto the outcome variable. It is based on the same idea that gamified or gameful motivational tools are most beneficial to younger ages [62]. The evidence presented here can help design optimal gamification interventions that maximize increases in K-12 learners' positive behavioral change.

\section{Conclusions}

The variations in gamification effect across different intervention length and the significant impact of moderators suggest that different conditions influence gamification's effects on behavior change. The present study results can provide useful information for educators to use gamification as an effective intervention strategy. Additional research is also needed to use more gamification types (i.e., online badge, leaderboard, progress bar, points, and avatar) and diverse programs in K-12 educational settings.

Author Contributions: Conceptualization, J.K. and D.M.C.; methodology, J.K. and D.M.C.; software, J.K.; validation, D.M.C.; formal analysis, J.K. and D.M.C.; investigation, J.K. and D.M.C.; resources, J.K.; data curation, J.K. and D.M.C.; writing-original draft preparation, J.K. and D.M.C.; writingreview and editing, D.M.C.; visualization, J.K.; supervision, D.M.C.; project administration, J.K. and D.M.C. All authors have read and agreed to the published version of the manuscript.

Funding: This research received no external funding.

Institutional Review Board Statement: The study was conducted according to the guidelines of the Declaration of Helsinki, and approved by the Institutional Review Board of The University of Texas at Austin (protocol code: 2019-03-0092, date of approval: 04/15/2019).

Informed Consent Statement: Not applicable.

Data Availability Statement: Not applicable.

Conflicts of Interest: The authors declare no conflict of interest.

\section{References}

1. Pintrich, P.R.; Zusho, A. Student Motivation and Self-ragulated Learning in the College Classroom. In Higher Education: Handbook of Theory and Research; Springer: Dordrecht, The Netherlands, 2002; pp. 55-128.

2. Cheong, C.; Cheong, F.; Filippou, J. Quick Quiz: A Gamified Approach for Enhancing Learning. In Proceedings of the PACIS 2013 Proceedings, Jeju Island, Korea, 18-22 June 2013; p. 206.

3. Auvinen, T.; Hakulinen, L.; Malmi, L. Increasing Students' Awareness of Their Behavior in Online Learning Environments with Visualizations and Achievement Badges. IEEE Trans. Learn. Technol. 2015, 8, 261-273. [CrossRef]

4. Kirschner, P.A.; Karpinski, A.C. Facebook reg. and academic performance. Comput. Hum. Behav. 2010, 26, 1237-1245. [CrossRef]

5. Hakulinen, L.; Auvinen, T.; Korhonen, A. Empirical Study on the Effect of Achievement Badges in TRAKLA2 Online Learning Environment. In Proceedings of the 2013 Learning and Teaching in Computing and Engineering, Institute of Electrical and Electronics Engineers (IEEE), Macau, China, 21-24 March 2013; pp. 47-54.

6. Anderson, A.; Huttenlocher, D.; Kleinberg, J.; Leskovec, J. Steering user behavior with badges. In Proceedings of the 22nd International Conference on Program Comprehension-ICPC 2014, Rio de Janeiro, Brazil, 13 May 2013; Association for Computing Machinery (ACM): New York, NY, USA, 2013; pp. 95-106.

7. Beemer, L.R.; Ajibewa, T.A.; DellaVecchia, G.; Hasson, R.E. A Pilot Intervention Using Gamification to Enhance Student Participation in Classroom Activity Breaks. Int. J. Environ. Res. Public Health 2019, 16, 4082. [CrossRef]

8. Domínguez, A.; Saenz-De-Navarrete, J.; De-Marcos, L.; Sanz, L.F.; Pagés, C.; Martínez-Herráiz, J.-J. Gamifying learning experiences: Practical implications and outcomes. Comput. Educ. 2013, 63, 380-392. [CrossRef]

9. Lee, J.J.; Hammer, J. Gamification in education: What, how, why bother? Acad. Exch. Q. 2011, 15, 146.

10. Liaw, S.-S. Investigating student: Perceived satisfaction, behavioral intention, and effectiveness of e-learning: A case study of the Blackboard system. Comput. Educ. 2008, 51, 864-873. [CrossRef]

11. Deci, E.L.; Koestner, R.; Ryan, R.M. A meta-analytic review of experiments examining the effects of extrinsic rewards on intrinsic motivation. Psychol. Bull. 1999, 125, 627. [CrossRef] [PubMed]

12. Deci, E.L.; Ryan, R.M. The "what" and "why" of goal pursuits: Human needs and the self-determination of behavior. Phycol. Inq. 2000, 11, 227-268. [CrossRef]

13. Niemiec, C.; Ryan, R.M. Autonomy, competence, and relatedness in the classroom: Applying self-determination theory to educational practice. Theory Res. Educ. 2009, 7, 133-144. [CrossRef]

14. Ryan, R.M. A motivational approach to self: Integration in personality. Perspect. Motiv. 1991, 38, $237-288$. 
15. Deterding, S. The lens of intrinsic skill atoms: A method for gameful design. Hum. Comput. Interact. 2015, 30, 294-335. [CrossRef]

16. Sailer, M.; Homner, L. The Gamification of Learning: A Meta-analysis. Educ. Psychol. Rev. 2019, 32, 77-112. [CrossRef]

17. Huang, R.; Ritzhaupt, A.D.; Sommer, M.; Zhu, J.; Stephen, A.; Valle, N.; Hampton, J.; Li, J. The impact of gamification in educational settings on student learning outcomes: A meta-analysis. Educ. Technol. Res. Dev. 2020, 68, 1875-1901. [CrossRef]

18. Deterding, S.; Dixon, D.; Khaled, R.; Nacke, L. From game design elements to gamefulness: Defining gamification. In Proceedings of the 15th International Academic MindTrek Conference: Envisioning Future Media Environments 2011, Tampere, Finland, 28 September 2011; pp. 9-15.

19. Huotari, K.; Hamari, J. Defining gamification: A service marketing perspective. In Proceedings of the 16th International Academic MindTrek Conference, Tampere, Finland, 3 October 2012; pp. 17-22.

20. Hamari, J.; Koivisto, J.; Sarsa, H. Does Gamification Work?-A Literature Review of Empirical Studies on Gamification. In Proceedings of the 2014 47th Hawaii International Conference on System Sciences, Waikoloa, HI, USA, 6-9 January 2014; pp. 3025-3034.

21. Abramovich, S.; Schunn, C.; Higashi, R.M. Are badges useful in education? It depends upon the type of badge and expertise of learner. Educ. Technol. Res. Dev. 2013, 61, 217-232. [CrossRef]

22. Moher, D.; Liberati, A.; Tetzlaff, J.; Altman, D.G. Preferred reporting items for systematic reviews and meta-analyses: The PRISMA statement. Ann. Int. Med. 2009, 151, 264-269. [CrossRef]

23. Walz, S.P.; Deterding, S. The Gameful World: Approaches, Issues, Applications; MIT Press: Cambridge, MA, USA, $2014 ;$ pp. 1-13.

24. Zichermann, G.; Cunningham, C. Gamification by Design: Implementing Game Mechanics in Web and Mobile Apps; O'Reilly Media, Inc.: Sebastopol, CA, USA, 2011.

25. Downs, S.H.; Black, N. The feasibility of creating a checklist for the assessment of the methodological quality both of randomised and non-randomised studies of health care interventions. J. Epidemiol. Community Health 1998, 52, 377-384. [CrossRef] [PubMed]

26. Ishikawa, S.; Kim, Y.; Kang, M.; Morgan, D.W. Effects of Weight-Bearing Exercise on Bone Health in Girls: A Meta-Analysis. Sports Med. 2013, 43, 875-892. [CrossRef]

27. Kim, K.; Ok, G.; Jeon, S.; Kang, M.; Lee, S. Sport-based physical activity intervention on body weight in children and adolescents: A meta-analysis. J. Sports Sci. 2016, 35, 1-8. [CrossRef]

28. Allam, A.; Kostova, Z.; Nakamoto, K.; Schulz, P.J. The effect of social support features and gamification on a Web-based intervention for rheumatoid arthritis patients: Randomized controlled trial. J. Med. Internet Res. 2015, 17, e14. [CrossRef]

29. De-Marcos, L.; Garcia-Cabot, A.; Garcia-Lopez, E. Towards the social gamification of e-learning: A practical experiment. Int. J. Eng. Educ. 2017, 33, 66-73.

30. De-Marcos, L.; Domínguez, A.; Saenz-De-Navarrete, J.; Pagés, C. An empirical study comparing gamification and social networking on e-learning. Comput. Educ. 2014, 75, 82-91. [CrossRef]

31. Denny, P.; McDonald, F.; Empson, R.; Kelly, P.; Petersen, A. Empirical Support for a Causal Relationship Between Gamification and Learning Outcomes. In Proceedings of the 2018 CHI Conference on Human Factors in Computing Systems-CHI '18, Montreal, QC, Canada, 21 April 2018; p. 311.

32. Hakulinen, L.; Auvinen, T.; Korhonen, A. The effect of achievement badges on student behavior: An Empirical Study in a University-Level Computer Science Course. Int. J. Emerg. Technol. Learn. 2015, 10, 18. [CrossRef]

33. Hamari, J. Do badges increase user activity? A field experiment on the effects of gamification. Comput. Hum. Behav. 2017, 71, 469-478. [CrossRef]

34. Hanus, M.D.; Fox, J. Assessing the effects of gamification in the classroom: A longitudinal study on intrinsic motivation, social comparison, satisfaction, effort, and academic performance. Comput. Educ. 2015, 80, 152-161. [CrossRef]

35. Harms, J.; Biegler, S.; Wimmer, C.; Kappel, K.; Grechenig, T. Gamification of Online Surveys: Design Process, Case Study, and Evaluation. In Human-Computer Interaction-INTERACT 2015; Lecture Notes in Computer Science; Springer Science and Business Media LLC: New York, NY, USA, 2015; pp. 219-236.

36. Huang, B.; Hew, K.F. Do points, badges and leaderboard increase learning and activity: A quasi-experiment on the effects of gamification. In Proceedings of the 23rd International Conference on Computers in Education, Hong Kong, China, 30 November 2015; pp. 275-280.

37. Kim, E.; Rothrock, L.; Freivalds, A. The effects of gamification on engineering lab activities. In Proceedings of the 2016 IEEE Frontiers in Education Conference (FIE), Erie, PA, USA, 12-15 October 2016; Institute of Electrical and Electronics Engineers (IEEE): Piscataway, NJ, USA, 2016; pp. 1-6.

38. Lam, Y.W.; Hew, K.F.; Chiu, K.F. Improving argumentative writing: Effects of a blended learning approach and gamification. Lang. Learn. Technol. 2018, 22, 97-118.

39. Landers, R.N.; Bauer, K.N.; Callan, R.C. Gamification of task performance with leaderboards: A goal setting experiment. Comput. Hum. Behav. 2017, 71, 508-515. [CrossRef]

40. Lombriser, P.; Dalpiaz, F.; Lucassen, G.; Brinkkemper, S. Gamified Requirements Engineering: Model and Experimentation. In Requirements Engineering: Foundation for Software Quality; Lecture Notes in Computer Science; Springer Science and Business Media LLC: New York, NY, USA, 2016; Volume 9619, pp. 171-187.

41. Ortiz-Rojas, M.; Chiluiza, K.; Valcke, M. Gamification through leaderboards: An empirical study in engineering education. Comput. Appl. Eng. Educ. 2019, 27, 777-788. [CrossRef] 
42. Poondej, C.; Lerdpornkulrat, T. The development of gamified learning activities to increase student engagement in learning. Aust. Educ. Comput. 2016, 31, 1-16.

43. Silpasuwanchai, C.; Ma, X.; Shigemasu, H.; Ren, X. Developing a Comprehensive Engagement Framework of Gamification for Reflective Learning. In Proceedings of the 2016 ACM Conference on Designing Interactive Systems-DIS '16, Brisbane, QLD, Australia, 4 June 2016; Association for Computing Machinery (ACM): New York, NY, USA, 2016; pp. 459-472.

44. Turan, Z.; Avinc, Z.; Kara, K.; Goktas, Y. Gamification and Education: Achievements, Cognitive Loads, and Views of Students. Int. J. Emerg. Technol. Learn. 2016, 11, 64-69. [CrossRef]

45. Cohen, J. Statistical Power Analysis for the Behavioral Sciences; Routledge, Taylor and Francis Inc.: New York, NY, USA, 1988.

46. Hedges, L.V.; Olkin, I. Statistical Methods for Meta-Analysis; Academic Press: New York, NY, USA, 1985; Volume 20. [CrossRef]

47. Borenstein, M.; Hedges, L.; Higgins, J.; Rothstein, H. Comprehensive Meta-Analysis Version 2. Comprehensive Meta-Analyses Software. 2005. Available online: https://www.meta-analysis.com/downloads/Meta-Analysis-Manual.pdf (accessed on 21 November 2019).

48. Hooper, P.; Jutai, J.W.; Strong, G.; Russell-Minda, E. Age-related macular degeneration and low-vision rehabilitation: A systematic review. Can. J. Ophthalmol. 2008, 43, 180-187. [CrossRef] [PubMed]

49. Egger, M.; Smith, G.D.; Schneider, M.; Minder, C. Bias in meta-analysis detected by a simple, graphical test. BMJ 1997, 315, 629-634. [CrossRef]

50. Wang, Y.-S.; Wu, M.-C.; Wang, H.-Y. Investigating the determinants and age and gender differences in the acceptance of mobile learning. Br. J. Educ. Technol. 2009, 40, 92-118. [CrossRef]

51. Morris, M.G.; Venkatesh, V. Age differences in technology adoption decisions: Implications for a changing workforce. Pers. Psychol. 2000, 53, 375-403. [CrossRef]

52. Venkatesh, V.; Morris, M.G.; Davis, G.B.; Davis, F.D. User acceptance of information technology: Toward a unified view. MIS Q 2003, 27, 425-478. [CrossRef]

53. Arning, K.; Ziefle, M. Understanding age differences in PDA acceptance and performance. Comput. Hum. Behav. 2007, 23, 2904-2927. [CrossRef]

54. Hamari, J.; Koivisto, J. "Working out for likes": An empirical study on social influence in exercise gamification. Comput. Hum. Behav. 2015, 50, 333-347. [CrossRef]

55. Ainslie, G. Specious reward: A behavioral theory of impulsiveness and impulse control. Psychol. Bull. 1975, 82, 463-496. [CrossRef]

56. Standage, M.; Duda, J.L.; Ntoumanis, N. A test of self-determination theory in school physical education. Br. J. Educ. Psychol. 2005, 75, 411-433. [CrossRef]

57. Nicholson, S. A RECIPE for Meaningful Gamification. In Gamification in Education and Business; Springer Science and Business Media LLC: New York, NY, USA, 2015; pp. 1-20.

58. Buckley, P.; Doyle, E. Gamification and student motivation. Interact. Learn. Environ. 2016, 24, 1162-1175. [CrossRef]

59. Davies, S.C.; Peltz, L.J. At-risk students in after-school programs: Outcomes and recommendations. Princ. Leadersh. 2010, 13, 12-16.

60. Jahnke, J. Student perceptions of the impact of online discussion forum participation on learning outcomes. J. Learn. Des. 2010, 3, 27-34. [CrossRef]

61. Tett, R.; Hundley, N.A.; Christiansen, N.D. Meta-Analysis and the Myth of Generalizability. Ind. Organ. Psychol. 2017, 10, 421-456. [CrossRef]

62. Koivisto, J.; Hamari, J. Demographic differences in perceived benefits from gamification. Comput. Hum. Behav. 2014, 35, 179-188. [CrossRef] 